\title{
LOG-CONVEXITY AND CAUCHY MEANS RELATED TO BERWALD'S INEQUALITY
}

\section{Naveed Latif, Josip PeČArić And IVAn Perić}

\begin{abstract}
In this paper, we investigate the famous Berwald's inequality. More precisely, we study the Berwald's difference in non-weighted and weighted case. We prove an interesting property of log-convexity of this difference which allows us to deduce Lyapunov's type inequality for these differences. Cauchy type means in this setting are also studied.

Mathematics subject classification (2010): 26D15.

Keywords and phrases: Berwald's inequality, weighted Berwald's inequality, log-convexity, Cauchy
\end{abstract} means.

\section{REFERENCES}

[1] Matloob Anwar And J. PeČArić, New Cauchy's means, J. Inequal. Appl. 2008, Article ID 163202,10 pages.

[2] G. H. Hardy, J. E. Littlewood, G. Pólya, Inequalities, Cambridge University Press, Cambridge, 1978.

[3] Naveed Latif, J. PeČArić And I. Perić, Some new results related to Favard's Inequality, J. Inequal. Appl. 2009, Article ID 128486, 14 pages.

[4] L. Maligranda, J. E. PeČArić, L. E. Persson, Weighted Favard's and Berwald Inequalities, J. Math. Anal. Appl. 190 (1995), 248-262.

[5] J. E. PeČarić, F. Proschan And Y. L. Tong, Convex functions, Partial Orderings and Statistical Applications, Academic Press, New York, 1992. 